\title{
Measuring Organizational Performance: A Case Study of Food Industry SMEs in Surabaya-Indonesia
}

\author{
Oliandes Sondakh ${ }^{1}$, Budiman Christiananta ${ }^{2}$, Lena Ellitan ${ }^{3}$ \\ ${ }^{1}$ Universitas Pelita Harapan Surabaya, Department of Management, \\ Surabaya, Indonesia \\ ${ }^{2,3}$ Universitas Katolik Widya Mandala Surabaya, School of Post Graduate, \\ Surabaya, Indonesia
}

\begin{abstract}
:
The concept of the Balance Scorecard is premised on the need for financial and non-financial indicators that enable a holistic measurement of performance of the organization. The food industry in Indonesia is experiencing positive and significant growth in their performance, however in terms of quality is still not satisfactory. Although performance measurement research has gain great interest, but the effectiveness of the Balance Score Card as a performance measurement tool for food industry SMEs in SurabayaIndonesia were not widely studied. This research objective was to determine the performance of food industry SMEs in Surabaya-Indonesia by using the Balance Scorecard as a performance measurement tool. This study was designed as a cross-sectional survey of the SMEs food industry in Surabaya-Indonesia. The population was 112 food industry SMEs in Surabaya from which 88 SMEs were used as a sample in this research. Primary data was collected using questionnaires which were administered to managers or owners in the firms. Data was analyzed using descriptive analysis and presented in tables. The study found that on average the respondents agree that they have good organizational performance. Organizational Performance based on Customers Perspective rated as the highest performance, followed by Learning and Growth Perspective; and Internal Business Process Perspective. The Financial Performance Perspective is rated relatively lower.
\end{abstract}

Keywords: Balance Scorecard, Organizational Performance, SMEs, Food Industry.

\section{Introduction}

Entering the era of free trade, the sector of Small and Medium Enterprises (SMEs) is seen to have a strategic role in driving the growth of a county's economy [1] [2] [3]. Empirical research shows that SMEs not only serves as a driver of the economy, but also a source of job creation [4] [5].

In Indonesia, SMEs are seen to have many advantages when compared to other forms of business. SME sector is considered as one of strongest economy pillar of the country. This can be seen during the 1998 economic crisis, in which the SME sector proved that they were able to withstand the collapse of the global economy. Contributions of the SME sector in determine the Gross Domestic Product (GDP) and as a producer of foreign exchange sector cannot be doubted also. With more than 57,9 million SMEs in Indonesia [6], SMEs can contribute $61.41 \%$ of Indonesia GDP and also able to absorb labor to almost $97 \%$. This strategic role is much better when compared to the achievement of major industry [7].

One of the regions that contributed significantly to the growth of Indonesia's national economy is East Java. As in 2015, the economic growth rate of East Java in 2016 has reached a higher number when compared with the national growth rate. In the second quarter of 2016, Indonesia's national economic growth reached $5.18 \%$ year on year (y-ony), while East Java economic growth has reached $5.62 \%$. Thus in the second quarter of 2016 East Java's contribution to the national economy has reached $14.77 \%$, with the value of Gross Regional Domestic Product (GRDP) on the base price of $\mathrm{Rp}$ 460.3 trillion, and GRDP at constant prices $\mathrm{Rp}$ 349.1 trillion [8]. Of this amount, approximately $20 \%$ of East Java GRDP is contributed by Micro Small Medium Enterprises (SMEs) and SMEs and Cooperatives, which is a generator of East Java's economic growth. This is because $92 \%$ of industries in East Java move in the sector of SMEs and SMEs [9]. 
As a region with the production growth in the manufacturing industry is higher compared to the national production growth, the East Java food industry in the third quarter of 2016, managed to become one of the top five industries experiencing significant production growth above $5 \%$ that is equal to $7.32 \%$ [10].

Furthermore, in 2016, food and beverage industry contributed $5.5 \%$ to the national GDP and $31 \%$ to the GDP of non-oil processing industry, and thus make the food and beverage industry as the sector with the largest contribution to the Indonesian economy [11].

The positive and significant performance of the food industry needs to be examined further. Chairman of the Association of Food and Beverage Indonesia (GAPMMI) stated that although the rate of growth of food and beverage industry is already quite good, but in terms of quality is still not satisfactory. This is because GAPMMI expect that growth should be achieved in terms of volume and not because of high prices. However, the phenomenon indicate that the growth in the food and beverage industry in the first and second quarter 2015 is still driven by price, while the growth in volume only seen in the third and fourth quarter 2015 [12]. This phenomenon showed the importance of research in examining the constructs of performance.

Performance is a multi-dimensional construct that consist of: financial based performance, which consist of income and expenses; customers based performance, innovation based performance, and employee based performance [13]. As shown here, the performance of the organization is not always obvious catch all the term. There is needs to be carefully observed the different aspects of the performance of the organization to measure the actual performance achieved by the company in the business year. Often times, an increase in one area may conflicting with other areas, or restraining the growth of the overall business.

For example, if there is an increase in performance-based budget, this may happen due to the reduction of employees and does not necessarily mean that there is an improvement in the performance of the organization. Another example is when there is a performance gain related to the innovation of new product launches. This does not mean there is an improvement in the performance of the organization, because the new product launch may not lead to increased sales, but instead it may harm the company if the new product is not accepted by the market. So there is a need to take every aspect cohesively with other aspects, to provide indepth understanding on company's overall objectives, to determine the performance of the organization.

On this basis, it is then Kaplan and Norton who introduced a performance measurement concept called the Balanced Scorecard [14]. The concept of Balanced Scorecard is a concept of performance measurement that combines measurement of financial and non-financial performance. Where the measurement of non-financial performance is an important thing to do because it will able the company to measure performance when the information related to "opportunity" is already available, though not yet financially realized [15]

The concept of the Balance Scorecard is premised on the need for financial and non-financial indicators that enable a holistic measurement of performance of the organization. Traditional performance measurement systems appear not to be providing managers with the information they need to measure and manage the all-important competencies that drive competitive advantage. Therefore, performance measurement incorporating non-financial measures has been a topic of great interest throughout most of the 1990s. Although performance measurement incorporating nonfinancial measurement has gain great interest, but the effectiveness of the Balance Score Card as a performance measurement tool in the East JavaIndonesia food industry SMEs were not widely studied. The research question therefore is: how is the performance of food industry SMEs in Surabaya City as one the capital of East Java-Indonesia. Thus, the objective of this study was to determine the performance of food industry SMEs in Surabaya City as one of the capital of East Java-Indonesia.

\section{Literature Review}

Organizational performance can be defined as the achievement of a business in accordance why the business was established, which are in general to gain maximum profit in order to sustain and to growth the development of the company. Performance represented the ability to work in the form of the result produced by a company in a given period, with reference to the prescribed standards. Therefore, the performance of the organization should be something that can be measured and describes the empirical condition of a company of any size, which refers to how well a company is able to became market-oriented businesses, and achieve their financial goals. Thus, it can be concluded that the performance is a measure of success, or 
achievement that has been achieved by a company, which is measured in each specified period [16].

Measuring the performance of organizations is not an easy thing [17]. Organizational performance is an indicator that can indicate the level of performance achieved by the company that can also be used to reflect the success of the manager / entrepreneur. This is because the performance of the company are normally achieved from the behavior of members of the company [18]. Performance of the organization is generally measure in terms of the company's financial ratios. Profit is a measure of the company's operational success. The company is said to have a competitive advantage if it has a high rate of profit above the average rate of normal profit.

There are several criteria that can be used to assess the performance of the organization, which includes the performance of the financial and nonfinancial. In measuring the performance of the organization, there are times when the criteria used are different. This is because the performance benchmarks are unique, because in practice, each company has its own peculiarities, like for example differences in terms of: business, background, legal status, capital structure, rate of growth, level of technology used by the company, and many more [19].

Traditionally the organization's performance is generally measured from the financial aspect, started from the profits achieved, the return on investment (Return on Investment / ROI), return on assets (Return on Assets / ROA), to the growth and innovation [20]. The financial aspect is intended to determine a company's ability to generate profits and to know how much the company is managed effectively. The manager's perception of corporate profits can be a good performance measure [21].

Over the long term, measurement models that focus on financial measures are indeed acceptable. But in the mid-1990s, the use of the financial aspects as benchmarks began to be questioned because it is seen to have many fundamental flaws. Therefore, Kaplan and Norton then developed a more comprehensive measure of corporate success, called the Balanced Scorecard. According to the Balanced Scorecard concept, organizational performance should be measured by using two benchmarks, which are: financial performance and non-financial performance [14].

Financial performance is typically assessed using measurement based on accounting data or financial data. The disadvantages of an accounting-based measurement system are its focus on past performance [14]. Company data from previous years is very weak to be used to indicate the future potential of a company. On that basis, the performance of the organization should not be measured based on accounting data only [22], but also should uses another data, like: the return on sales, profitability, sales growth, productivity improvement, production costs improvement, and many more [23].

Balance Scorecard popularity shows that nonfinancial performance is one of the important aspect of organizational performance measurement [14]. Non-financial performance is also known as operational performance, where its aspects is able to measure performance when the information related with opportunities already available, but not yet realized financially [15]. Operational performance can be measured by using measurements such as market share, new products launch, quality, marketing effectiveness, and customers satisfaction [15] [24].

In more detail, the concept of the Balanced Scorecard states that to achieve competitive advantage, the organization's performance should be measured through four areas based on: Financial Perspective, Customers Perspective, Internal Business Process Perspective, and Learning and Growth Perspective [14].

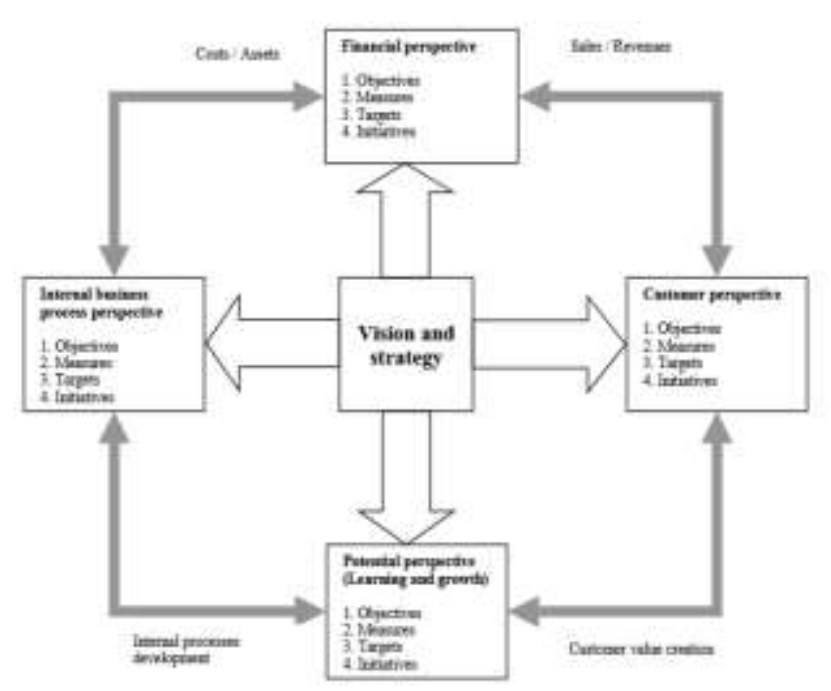

Figure 1. The Balanced Scorecard framework Note. Kaplan and Norton (1996)

\section{Financial perspective}

In the financial perspective, the company is expected to increase their market share, and also raise revenue through the sale of the company's products; and in addition, increases costeffectiveness and asset utilization in order to increase the company's productivity. 


\section{Customers perspective}

In the customers's perspective, the company must identify the needs of its customers and its market segments. Identifying customers needs appropriately can help companies to provide service to customers.

\section{Internal business process perspective}

In internal business processes perspective, companies need to identify the most critical processes that must be considered, to achieve the goal of increasing value for customers, and the purpose of increasing the financial value.

\section{Learning and growth perspective}

In learning and growth perspective, companies must identify the objectives set out in the financial perspective, customers perspective, internal business processes perspective, and determine where the company should have to excel, in order to achieve performance breakthrough. Learning and growth perspective will provide information regarding the infrastructure to enable these ambitious goals in all three of the other perspective is reached. The objectives in the learning and growth perspective is a controller to achieve excellence results of all three perspectives.

\section{Research Method}

Research design constitutes the blue print for collection, measurement, and analysis of data. This research study was a cross-sectional survey of food industry SMEs in Surabaya. The proposed study population comprised of 112 SMEs. This is because in accordance with the research objectives that have been proposed, this research uses purposive sampling technique, where this technique requires the way sampling based on certain criteria. The sampling criteria used in this study are:

1. Located in Surabaya

2. The age of $S M E$ is $\geq 3$ years

SMEs are a vulnerable type of business, and have a high failure rate. More than $70 \%$ of SMEs failed during the first three years of their operations. Statistics show that eight out of ten new ventures fail within the first three years [25]. On that basis, according to the research objectives to be achieved, this study took a sample of SMEs that have stood for more than three years.

3. Categorized as medium-sized enterprises

The smaller the organization, the more difficult it is to determine its limits [26]. Small businesses, consisting of one or several people, are generally composed of the same family members, and strongly influenced by family inheritance, making it vulnerable to bias. On that basis, in accordance with the research objectives to be achieved, this study took a sample of SMEs with medium scale.

Based on data from the Central Bureau of Statistics, the number of food industry SMEs in accordance with the characteristics established in the area of Surabaya is as many as 112 SMEs. This study in determining the number of samples using Slovin formula:

$\mathrm{n}=\frac{\mathrm{N}}{1+\mathrm{Ne} 2}$

Where:

$\mathrm{n}=$ number of sample

$\mathrm{N}=$ population size

$\mathrm{e}=$ level of error

In this research the value of $\mathrm{e}$ is $5 \%$, so the minimum sample amount used by researchers is 88 SMEs.

Questionnaires were used to collect primary data and the respondents were the owner / general managers in each of the firms. The questionnaires were administered using drop and pick later method.

The results of the survey were analyzed using descriptive statistics of mean and standard deviation to interpret the 5-point Likert scale type responses. Each element of the four elements of the balance scorecard were analyzed using frequencies and percentages to enable independent assessment of the effectiveness of each element as well as appraise the overall effectiveness of the tool in the industry.

\section{Findings}

Validity test is done through Pearson Product Moment Correlation testing. The test results show that the Pearson Product Moment Correlation value between each indicator with the total score of the variable yields a significance value of $\leq 0.05(\alpha=$ $5 \%$ ), so it can be stated that all the indicators tested in this study are valid and thus it can be concluded that the statement- the statements in the questionnaire (indicator) are quite representative in measuring Organizational Performance.

TABEL 1. VALIDITY TEST

\begin{tabular}{|c|l|c|c|c|}
\hline Dimensions & Indicators & Corr. & Sig. & Concl. \\
\hline $\begin{array}{c}\text { Financial } \\
\text { Perspective }\end{array}$ & $\begin{array}{l}\text { Actual number of annual sales } \\
\text { units against predetermined } \\
\text { targets (fp1) }\end{array}$ & 0.641 & 0.000 & Valid \\
\cline { 2 - 5 } & Actual number of annual sales & 0.747 & 0.000 & Valid \\
\hline
\end{tabular}




\begin{tabular}{|c|c|c|c|c|}
\hline & $\begin{array}{l}\text { values against predetermined } \\
\text { targets (fp2) }\end{array}$ & & & \\
\hline & $\begin{array}{l}\text { Actual number of annual } \\
\text { collections against } \\
\text { predetermined targets (fp3) }\end{array}$ & 0.690 & 0.000 & Valid \\
\hline & $\begin{array}{l}\text { Actual number of annual profits } \\
\text { against predetermined targets } \\
\text { (fp4) }\end{array}$ & 0.724 & 0.000 & Valid \\
\hline & $\begin{array}{l}\text { Actual number of annual costs } \\
\text { against predetermined targets } \\
\text { (fp5) }\end{array}$ & 0.678 & 0.000 & Valid \\
\hline \multirow{3}{*}{$\begin{array}{l}\text { Customers } \\
\text { Perspective }\end{array}$} & Customers satisfaction (cp1) & 0.655 & 0.000 & Valid \\
\hline & Product value (cp2) & 0.615 & 0.000 & Valid \\
\hline & Market share growth (cp3) & 0.464 & 0.000 & Valid \\
\hline \multirow{3}{*}{$\begin{array}{c}\text { Internal } \\
\text { Business } \\
\text { Process } \\
\text { Perspective }\end{array}$} & $\begin{array}{l}\text { Timeliness of product } \\
\text { innovation development (ibp1) }\end{array}$ & 0.420 & 0.000 & Valid \\
\hline & Timeliness of production (ibp2) & 0.654 & 0.000 & Valid \\
\hline & Internal audit result (ibp3) & 0.689 & 0.000 & Valid \\
\hline \multirow{4}{*}{$\begin{array}{l}\text { Learning } \\
\text { and Growth } \\
\text { Perspective }\end{array}$} & $\begin{array}{l}\text { Employee key performance } \\
\text { indicators result ( }(\operatorname{lgp} 1)\end{array}$ & 0.576 & 0.000 & Valid \\
\hline & Employee satisfaction (lgp2) & 0.605 & 0.000 & Valid \\
\hline & $\begin{array}{l}\text { Rate of employee violation (R) } \\
(\operatorname{lgp} 3)\end{array}$ & 0.559 & 0.000 & Valid \\
\hline & Number of training (lgp4) & 0.713 & 0.000 & Valid \\
\hline
\end{tabular}

Reliability test is done through Cronbach Alpha testing. The test results show that the Cronbach Alpha value yields a value of $\geq 0.6$, so it can be stated that all the indicators tested in this study are reliable and thus it can be concluded that the statements in the questionnaire (indicator) are quite consistent in measuring the variable.

\section{TABEL 2. RELIABILITY TEST}

\begin{tabular}{|c|c|c|}
\hline Variable & Cronbach Alpha & Concl. \\
\hline Organizational Performance & 0,887 & reliable \\
\hline
\end{tabular}

Organizational Performance consist of four dimensions, namely: Financial Perspective, Customers Perspective, Internal Business Process Perspectives, and Learning and Growth Perspectives.

TABEL 3. DESCRIPTION OF RESPONDENTS ANSWER FOR ORGANIZATIONAL PERFORMANCE

\begin{tabular}{|l|l|l|l|}
\hline No. & \multicolumn{1}{|c|}{ Dimensions } & Mean & Concl. \\
\hline 1 & Financial Perspective & 3.54 & Agree \\
\hline 2 & Customers Perspective & 3.97 & Agree \\
\hline 3 & Internal Business Process Perspective & 3.83 & Agree \\
\hline 4 & Learning and Growth Perspective & 3.86 & Agree \\
\hline \multicolumn{2}{|l|}{ Average } & 3.80 & Agree \\
\hline
\end{tabular}

Table 3 shows the mean average of respondent's answer to the Organizational Performance is 3.80; which means that on average the respondents agree that they have good organizational performance. Organizational Performance based on Customers Perspective rated as the highest performance, this is reflected from the mean value of 3.97 , followed by Learning and Growth Perspective with the mean value of 3.86, and Internal Business Process Perspective with the mean value of 3.83 . The Financial Performance Perspective is rated relatively lower, this is reflected from the mean value, which is only 3.54 .

A detailed description of the respondent's answer to the dimensions of Organizational Performance are as follows:

TABEL 4. DESCRIPTION OF RESPONDENTS ANSWER FOR FINANCIAL PERSPECTIVE

\begin{tabular}{|c|c|c|c|c|c|c|c|c|}
\hline \multirow[t]{2}{*}{ No. } & \multicolumn{5}{|c|}{ Likert Scale } & \multirow[t]{2}{*}{ Mean } & \multirow[t]{2}{*}{ Concl. } & \multirow[t]{2}{*}{ Std. Dev } \\
\hline & 1 & 2 & 3 & 4 & 5 & & & \\
\hline fp1 & 0 & 11 & 29 & 42 & 6 & 3,49 & Agree & 0,802 \\
\hline $\mathrm{fp} 2$ & 0 & 9 & 28 & 45 & 6 & 3,55 & Agree & 0,772 \\
\hline $\mathrm{fp} 3$ & 0 & 12 & 25 & 39 & 12 & 3,58 & Agree & 0,893 \\
\hline $\mathrm{fp} 4$ & 0 & 10 & 30 & 39 & 9 & 3,53 & Agree & 0,830 \\
\hline $\mathrm{fp} 5$ & 0 & 14 & 21 & 44 & 9 & 3,55 & Agree & 0,883 \\
\hline \multicolumn{6}{|c|}{ Financial Perspective } & 3.54 & Agree & \\
\hline
\end{tabular}

Table 4 shows the mean average of respondent's answer to the Financial Perspective is 3.54; which means that on average the respondents agree that they have good performance based on financial perspective. Actual number of annual collections against predetermined targets rated as the highest performance based on financial perspective, this is reflected from the mean value of 3.58 , followed by actual number of annual sales values against predetermined targets and actual number of annual costs against predetermined targets with the mean value of 3.55. Actual number of annual profits against predetermined targets and actual number of annual sales units against predetermined targets are rated relatively lower, this is reflected from the mean value, which is only 3.53 and 3.49 respectively.

TABEL 5. DESCRIPTION OF RESPONDENTS ANSWER FOR CUSTOMERS PERSPECTIVE

\begin{tabular}{|c|c|c|c|c|c|c|c|c|}
\hline \multirow[t]{2}{*}{ No. } & \multicolumn{5}{|c|}{ Likert Scale } & \multirow[t]{2}{*}{ Mean } & \multirow[t]{2}{*}{ Concl. } & \multirow[t]{2}{*}{ Std. Dev } \\
\hline & 1 & 2 & 3 & 4 & 5 & & & \\
\hline cp1 & 0 & 0 & 24 & 52 & 12 & 3,86 & Agree & 0,628 \\
\hline $\mathrm{cp} 2$ & 0 & 3 & 15 & 55 & 15 & 3,93 & Agree & 0,691 \\
\hline cp3 & 0 & 0 & 15 & 49 & 24 & 4,10 & Agree & 0,662 \\
\hline \multicolumn{6}{|c|}{ Customers Perspective } & 3.97 & Agree & \\
\hline
\end{tabular}

Table 5 shows the mean average of respondent's answer to the Customers Perspective is 3.97 ; which means that on average the respondents agree that they have good performance based on customers' perspective. Market share growth rated as the highest performance based on customers perspective, this is reflected from the mean value of 4.10. Product value and customers satisfaction are rated relatively lower, this is reflected from the mean value, which is only 3.93 and 3.86 respectively. 
TABEL 6. DESCRIPTION OF RESPONDENTS ANSWER FOR INTERNAL BUSINESS PROCESS PERSPECTIVE

\begin{tabular}{|c|c|c|c|c|c|c|c|c|}
\hline \multirow[t]{2}{*}{ No. } & \multicolumn{5}{|c|}{ Likert Scale } & \multirow[t]{2}{*}{ Mean } & \multirow[t]{2}{*}{ Concl. } & \multirow[t]{2}{*}{ Std. Dev } \\
\hline & 1 & 2 & 3 & 4 & 5 & & & \\
\hline ibp1 & 3 & 6 & 12 & 39 & 28 & 3,94 & Agree & 1,021 \\
\hline ibp2 & 0 & 3 & 28 & 42 & 15 & 3,78 & Agree & 0,765 \\
\hline ibp3 & 0 & 3 & 31 & 39 & 15 & 3,75 & Agree & 0,777 \\
\hline \multicolumn{6}{|c|}{ Internal Business Process Perspective } & 3.83 & Agree & \\
\hline
\end{tabular}

Table 6 shows the mean average of respondent's answer to the Internal Business Process Perspective is 3.83; which means that on average the respondents agree that they have good performance based on internal business process perspective. Timeliness of product innovation development rated as the highest performance based on internal business process perspective, this is reflected from the mean value of 3.94. Timeliness of production and internal audit result are rated relatively lower, this is reflected from the mean value, which is only 3.78 and 3.75 respectively.

TABEL 7. DESCRIPTION OF RESPONDENTS ANSWER FOR LEARNING AND GROWTH PERSPECTIVE

\begin{tabular}{|c|c|c|c|c|c|c|c|c|}
\hline \multirow[t]{2}{*}{ No. } & \multicolumn{5}{|c|}{ Likert Scale } & \multirow[t]{2}{*}{ Mean } & \multirow[t]{2}{*}{ Concl. } & \multirow[t]{2}{*}{ Std. Dev } \\
\hline & 1 & 2 & 3 & 4 & 5 & & & \\
\hline $\operatorname{lgp} 1$ & 0 & 3 & 26 & 41 & 18 & 3,84 & Agree & 0,786 \\
\hline $\operatorname{lgp} 2$ & 0 & 0 & 18 & 49 & 21 & 4,03 & Agree & 0,669 \\
\hline $\operatorname{lgp} 3$ & 0 & 3 & 27 & 43 & 15 & 3,80 & Agree & 0,761 \\
\hline $\operatorname{lgp} 4$ & 0 & 6 & 32 & 26 & 24 & 3,77 & Agree & 0,931 \\
\hline \multicolumn{6}{|c|}{ Learning and Growth Perspective } & 3.86 & Agree & \\
\hline
\end{tabular}

Table 7 shows the mean average of respondent's answer to the Learning and Growth Perspective is 3.86; which means that on average the respondents agree that they have good performance based on learning and growth perspective. Employee satisfaction rated as the highest performance based on learning and growth perspective, this is reflected from the mean value of 3.86. Employee key performance indicators result and rate of employee violation are rated relatively lower, this is reflected from the mean value, which is only 3.84 and 3.80 , last followed by number of training with the mean value of 3.77 .

\section{Discussion}

Performance is the measure of success or achievement that has been achieved by a company that is measured in each specified period [16]. Specific attributes that can be used to measure the performance of the organization are: financial perspective, customers' perspective, internal business process performance perspective, and learning and growth perspective.

The result from descriptive statistic of the respondents answer indicate that the average of the food industry SMEs in Surabaya assess their organizational performance is high. The highest performance is based on customers' perspective. This is because all the respondents in this study already existed for more than three years, so the respondents assumed they already have a large number of loyal customers, which basically support them to sustain and growth. Furthermore, a large number of loyal customers are perceived to give them an advantage in terms of information. That is manifested in the form of knowledge to be processed by SMEs through the process of learning and growth, to bring a breakthrough in the internal business process. This is why the learning and growth perspective is perceived as the second highest performance, followed by internal business process perspective at the third. Meanwhile, financial perspectives perceived at the lowest performance compare to the others. This is because food industry is an industry where the level of competition environment is quite dynamic, so it is not easy to reach the optimal level of profit.

The result from descriptive statistic of the respondents answer indicate that the average of the food industry SMEs in Surabaya assess their organizational performance based on customers' perspective is high. Market share growth rated as the highest performance based on customers perspective, followed by product value and customers satisfaction.

The average respondents perceived that food industry nowadays is still growing, these create opportunity and give chance them to increase their market share. To catch the opportunity, they need to create products that have a high value on customers' perception and by the end hopefully created customers' satisfaction. Customers' satisfaction is not easily created because food products are low involvement products, so customers can easily switch form one product to another products. Despite it is perceived at the lowest, this indicator is still on high value, which means that the average respondents still perceived the level of their customers' satisfaction is good.

The result from descriptive statistic of the respondents answer indicate that the average of the food industry SMEs in Surabaya assess their organizational performance based on learning and growth perspective is high. Employee satisfaction rated as the highest performance based on learning and growth perspective, followed by employee Key Performance Indicators result, rate of employee violation, and number of training. 
The average respondents perceived that the satisfaction of employees of their company is high. This is reflected in the low turnover rate in their company. Employees are also perceived to indicate a high organizational behavior, which is shown on the achievement of Key Performance Indicators are high and low rates of violation. However, majority of the respondents still perceive employee training as a cost to the company's budget. This is because the limitation in their capital, which most of their resources are allocated to other activities that they consider more important. However, despite the lowest perceived perceptions, this indicator is still of high value, meaning that the average respondents still perceives that training is an important thing to do, especially to improve the learning process and growth in the company, although the focus level is not as high as others aspect.

The result from descriptive statistic of the respondents answer indicate that the average of the food industry SMEs in Surabaya assess their organizational performance based on internal business process perspective is high. Timeliness of product innovation development rated as the highest performance based on internal business process perspective, followed by timeliness of production and internal audit result.

The average respondents perceived that product development innovation is important in the food industry. Dynamic competitive environment requires companies to routinely release a new product, and ensure the products produced by the company are available at the time and the right amount on the market. However, the challenges in SMEs, is majority of the SMEs still do not have a detail Standard Operating Procedure (SOP). So, in the implementation, there are still various weaknesses found, like consistency. Although perceived as the lowest indicator, but the value is still high. This means majority of the respondents still perceived that the operational processes that run in the company is in accordance with established SOP.

The result from descriptive statistic of the respondents answer indicate that the average of the food industry SMEs in Surabaya assess their organizational performance based on financial perspective is high. Actual number of annual collections against predetermined targets rated as the highest performance based on financial perspective, followed by actual number of annual sales values against predetermined targets, actual number of annual costs against predetermined targets, actual number of annual profits against predetermined targets, and actual number of annual sales units against predetermined targets.

The average owner of respondents perceived that the relationship between the company and the customers is high. This is reflected in the low level of bad credit in their companies. The level of customers' acceptance of the company's products is also perceived to be high, despite rising prices, driven by increased costs because of the dynamic competition. The dynamic competition in the food industry also causes the respondents to perceive companies have difficulty reaching the level of profit set. Despite the lowest perceived value, all the indicators still have high value, meaning that the average owner of SME food industry in Surabaya perceives that the profit targets and sales units achieved by the company still in accordance with the target set.

\section{Conclusion}

The food industry in Surabaya-Indonesia is still growing. The strength of food industry SMEs in Surabaya-Indonesia is their good relation with customers. The food industry SMEs in SurabayaIndonesia also found to be a learning organization. The overall performance of food industry SMEs in Indonesia is good, even though still need some improvement in international business process and financial aspect.

\section{References}

1. S. Husband \& M. Purnendu, "A Conceptual Model for Quality Integrated Management in Small and Medium Size Enterprise", International Journal of Quality \& Reliability Management, Vol. 16, No. 7, pp. 699-713, 1999.

2. C. M. Mahemba, Innovation Management Practices of Small and Medium Scale Enterprises in Tanzania, Doctoral Dissertation, University of Twente.

3. T. Tambunan, "Promoting Small and Medium Enterprises with a Clustering Approach: A Policy Experience from Indonesia", Journal of Small Business Management, Vol. 43, No. 2, pp.138-154, 2005.

4. S. Collinson \& J. Houlden, "Decision-Making and Market Orientation in the Internationalization Process of Small and Medium Sized Enterprises", Management International Review, Vol. 45, No. 4, pp. 413436, 2005.

5. S. Radas \& L. Bozic, "The Antecedents of SME Innovativeness in a Merging Transition 
Economy", Technovation, Vol. 29, No. 6-7, pp. 438-450, 2009.

6. M. B. Baihaqi, "UKM Bantu Atasi Masalah Ekonomi Indonesia", November 19, 2015. [Online]. Available: http://www.neraca.co.id/article/61707/ukmbantu-atasi-masalah-ekonomi-indonesia. [Accessed: October 11, 2016].

7. A. Utantoro, "Kontribusi IKM Jauh Lebih Bagus Dibanding Industri Besar", January 30, 2017. [Online]. Available: http://mediaindonesia.com/news/read/89861/kon tribusi-ikm-jauh-lebih-bagus-dibanding-industribesar/2017-01-30. [Accessed: October 11, 2016].

8. JPNN.com, "Kalahkan Nasional, Ekonomi Jatim Melaju Kencang”, August 06, 2016. [Online]. Available:

https://www.jpnn.com/news/kalahkan-nasionalekonomi-jatim-melaju-kencang. [Accessed: October 11, 2016].

9. jatimprof.go.id, "Koperasi dan UKM Jadi Generator Pertumbuhan di Jawa Timur", January 25, 2016. [Online]. Available: http://jatimprov.go.id/read/beritapengumuman/koperasi-dan-ukm-jadi-generatorpertumbuhan-di-jawa-timur. [Accessed: October 11, 2016].

10. Badan Pusat Statistik, "Pertumbuhan Produksi Industri Manufaktur Triwulan III Tahun 2016 Jawa Timur", November 01, 2016. [Online]. Availabe: https://jatim.bps.go.id/4dm!n/brs_ind/brsInd20161101145100.pdf. [Accessed: October 11, 2016].

11. Tribunbisnis, "Sepanjang Tahun 2016 Ini, Pertumbuhan Industri Makanan dan Minuman Stabil", July 27, 2016. [Online]. Available: http://www.tribunnews.com/bisnis/2016/07/27/s epanjang-tahun-2016-ini-pertumbuhan-industrimakanan-dan-minuman-stabil?page $=2$.

[Accessed: October 11, 2016].

12. Republika, "Menakar Prospek Industri Makanan dan Minuman". [Online]. Available: http://www.kemenperin.go.id/artikel/14292/Men akar-Prospek-Industri-Makanan-dan-Minuman. [Accessed: October 11, 2016].

13. B. J. Jaworski \& A. K. Kohli, "Market orientation: Review, Refinement, and Roadmap", Journal of Market-Focused Management, Vol. 1, No. 2, pp. 119-135, 1996.

14. R. S. Kaplan \& D. P. Norton, "The Balanced Scorecard: Measures that Drive Performance", Harvard Business Review, 1992.
15. R. B. Carton, Measuring Organizational Performance: An Exploratory Study, Doctoral Dissertation. The University of Georgia.

16. J. Bae \& J. Lawler, "Organizational and HRM Strategies in Korea: Impact on Firm Performance in an Emerging Economy", Academy of Management Journal, Vol. 43, No. 3, pp. 502-517, 2000.

17. Brigman, Social Psychology, New York: HarperCollins, 1992.

18. J. L. Gibson, J. M. Ivancevich \& J. H. Donnelly, Organizations: Behavior, Structure, Processes. London: Irwin Professional Publishing, 1998.

19. D. Hatmoko, Persepsi Pimpinan Bumn Terhadap Eugibilitas Balance Scorcard Sebagai Sistem Penilaian Kinerja Perusahaan, Master Tesis. Universitas Diponegoro, 2000.

20. D. R. Denison \& A. K. Mishra, "Toward a Theory of Organizational Culture and Effectiveness", Organization Science, Vol. 6, No. 2, pp. 204-223, 1995.

21. J. Dawes, "Market Orientation and Company Profitability: Further Evidence Incorporating Longitudinal Data", Australian Journal of Management, Vol. 25, No. 2, pp. 173-199, 2000.

22. G. Ursula \& C. P. M. Wilderom, Organizational Effectiveness=Corporate Performance? Why and How Two Research Traditions Need To Be Merged, Netherlands: Tilburg University, 1997.

23. I. M. Prieto \& E. Revila, "Learning Capability and Business Performance: A Non-Financial and Financial Assessment", Journal of the Learning Organization, Vol. 13, No. 2, pp. 166-185, 2006.

24. R. B. Carton \& C. W. Hofer, Measuring Organizational Performance: Metrics for Entrepreneurship and Strategic Management Research, Cheltenham: Edward Legard Publishing Ltd, 2006.

25. M. K. Mason, "Research on Small Businesses". [Online]. Available: http://www.moyak.com/papers/small-businessstatistics.html. [Accessed: October 11, 2016].

26. M. J. Brand \& E. H. Bax, "Strategic HRM for SMEs: Implications for Firms and Policy", Education + Training Journal Vol. 44, No. 8, pp. 451-463, 2002. 
Author Profile

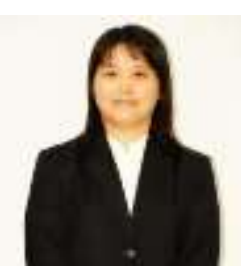

Oliandes Sondakh received S.E. degree in Marketing Management and M.M. degree in Strategic Management from Universitas Katolik Widya Mandala Surabaya in 2002 and 2006, respectively. Currently, she is a Dr (cand.) in Postgraduate School of Universitas Katolik Widya
Mandala Surabaya and lecturer at Universitas Pelita Harapan Surabaya.

Budiman Christiananta, MA., Ph.D., Drs. Ec is a lecturer at Postgraduate School of Universitas Katolik Widya Mandala Surabaya.

Dr. Lenna Ellitan is a lecturer at Postgraduate School of Universitas Katolik Widya Mandala Surabaya. 